\title{
Efficacy of Meditative Prayer on Guilt Feelings, Inferiority \& Insecurity
}

MANJU DEORARI, MRIGNAYANI AGARWAL and PRATIMA SHUKLA

\begin{abstract}
Aim of the present study was to examine the efficacy of Meditative-Prayer on the feelings of Guilt, Inferiority and Insecurity among college going students. Experimental and control group design was used. Sixty sample were collected through accidental sampling (30 in control group and 30 in experimental group) from M.B.P.G College, Haldwani (Nainital). The students who had high levels of guilt, inferiority and insecurity feelings were selected. The age of the subjects ranged from 18-26 years. The students in the experimental group were made to do Meditative Prayer regularly for 30 days. Bhramavarchas Guilt Feeling Test and the Inferiority-Insecurity Scale were used. The obtained value of $x^{2}$ for Guilt and Inferiority feelings is significant at 0.01 level and Insecurity feeling is significant at 0.05 level of confidence. The result of the study shows that Meditative Prayer is significantly effective in reducing the levels of Guilt, Inferiority and Insecurity Feelings.
\end{abstract}

Key-words: Meditative Prayer, Guilt, Inferiority and Insecurity.

Nothing gives one person so much advantage over another as the ability to remain cool and unruffled under all circumstances. Life would be simple indeed if all our needs were automatically satisfied. In reality, however, many obstacles, both personal and environmental, prevent this ideal situation. The world is changing with incredible rapidity and established customs, traditions and values are changing with it (Khokhar, 2003). The growth of knowledge gained by the human society in this age of information explosion is truly remarkable. But on the other hand we are facing some multidimensional hazards which were never visualized before.

With one look at the world, not one or two but hundreds of people can be seen making merry, talking and smiling and in a pleasant state. Looking at them, it is difficult to say that in their lives there is any pain or unhappiness, any discord or discontentment. But what is seen is not the truth. Their happiness is just like someone is laughing or being happy in a dream or unconscious. Their happiness is neither original nor permanent. At that time either they are satisfied with enjoyment of some object or charmed with some gain or profit. If the cause of their pleasure is identified and removed, then all their cheerfulness would be destroyed.

What people want is peace of mind. When one starts to make a list of things that upset peace of mind, the catalogue is almost endless. And even the person who seems to "have everything" from external appearance, is never completely happy, because inside something keeps gnawing or tugging at his heart. When mind identifies oneself with the senses, it tends to create oppression on the usual strong condition of the body. This, in turn, leads to various forms of mental disturbances. These disturbances include feelings of guilt, inferiority, insecurity etc.

Guilt is that part of human conscience that convicts us for actions and thoughts. It is a state in which one experiences conflict at having done something that one believes one should not have done. Feelings of guilt make the person lose 
confidence in his ability to achieve what he sets out to do (Hurlock, 2002). Guilt is a perception of one's apparent dislodgement from his core role structure. Feeling of guilt if not gotten rid of grows like cancer and destroys ones mental peace (Vasudevan, 2003).

Iinferiority complex is a feeling that one is inferior to others in some way. Such feelings can arise from an imagined or actual inferiority in the afflicted person. Feelings of inferiority arise from a sense of incompleteness or imperfection in any sphere of life (Hall, Lindzey \& Campbell, 2002).

Insecurity is a feeling of general unease or nervousness that may be triggered by perceiving one to be unloved, inadequate or worthless. Insecurity is the feeling of being unable to cope, feeling unsafe, threatened or anxious (Atkinson, Berne and Woodworth, 1996). It can stem from the individual's immediate environment. Insecurity can be distressing and feel threatening to the psyche. In a study of college students it was noted that more than $90 \%$ had experienced feeling of inadequacy (Page, 2003).

Prayer means to ask earnestly, beseech or implore. Prayer develops faith, devotion and self-confidence. "Prayer is a science that possesses powers to transform a man" (Sharma, 2005). Feelings have an important place in prayer (Saraswati, 1998). Prayer requires a living faith in God. It is as real as the force of gravity. The results of a research by Harris et al., (1999) suggested that prayer may be an effective adjunct to standard medical care. Meditative prayer thus provides a serene means of establishing harmony and well-being in the body and minds of individuals.

\section{METHODOLOGY}

\section{Sample and Sampling}

A sample of 60 students was selected through accidental sampling from M.B.P.G. College,
Haldwani (Distt. Nainital), all having high levels of Guilt and Inferiority-Insecurity feelings and this sample was divided into two groups (one control and one experimental). The experimental group was made to do Meditative-Prayer for 30 days. The age of the subjects ranged from 18-26 years.

\section{Research Design}

In the present study Control and Experimental Group Design was used. In this design, the sample having same value of pre-test data is divided into two groups- one experimental (one that received the intervention) and one control (the one that did not receiving any intervention). The post data is collected for both the groups and compared with each other. Any significant difference indicates the efficacy of the intervention given to the experimental group.

\section{Procedure}

Sixty sample were selected through accidental sampling and were divided into two groups- one experimental (one who receiving the intervention) and one control (the one do not receiving any intervention). The students in the experimental group were made to do Meditative Prayer regularly for 30 days as follows: Step (I): The subjects were seated comfortably in a hall in the morning. Then the subjects were made to sit in a comfortable and straight meditative posture and were told to relax their whole body. They were told to close their eyes gently and become aware about each and every part of their body and their breathing process. Then the subjects were made to chant "OM" five times to prepare themselves for prayer. This step took 5 minutes. Step (II): The subjects were made to do the Prayer ("Itni shakti humen dena data ...") for 15 minute. Step (III): After completion of the prayer the subjects were told to rub their palms gently and put their palms on their eyes. They were then told to open their 
eyes inside their palms and blink their eyes slowly and gently, and then come out of the meditativeprayer and become aware of their surroundings.The outcome measures were assessed in both groups before and after the study.

\section{Tools}

The Bhramavarchas Guilt Feeling Test (Mishra and Saini, 2007) and the Inferiority-Insecurity Scale (Pati, 1989).

\section{Statistical analysis}

After collection and scoring of research data, the obtained data were statistically analyzed through Chi-square $\left(x^{2}\right)$ test.

\section{RESULTS}

Null Hypotheses (1): There is no significant difference between the levels of Guilt feelings of group subjected to meditative-prayer and the group not subjected to meditative-prayer.

\section{Percentage Table (1a):}

\begin{tabular}{|c|c|c|c|}
\hline Groups & $\begin{array}{c}\text { Above } \\
\text { average } \\
\text { (75 \& up) }\end{array}$ & $\begin{array}{c}\text { Averag } \\
\text { e } \\
\text { (28-75) }\end{array}$ & $\begin{array}{c}\text { Below } \\
\text { Average } \\
\text { (28 \& below) }\end{array}$ \\
\hline $\begin{array}{c}\text { Experimental } \\
\text { group }\end{array}$ & $6.67 \%$ & $46.67 \%$ & $46.67 \%$ \\
\hline Control group & $40 \%$ & $33.33 \%$ & $26.67 \%$ \\
\hline
\end{tabular}

\section{Result Table (1b):}

\begin{tabular}{|c|c|c|c|c|}
\hline Groups & $\begin{array}{c}\text { Above } \\
\text { average } \\
\text { (75 \& up) }\end{array}$ & $\begin{array}{c}\text { Average } \\
(28-75)\end{array}$ & $\begin{array}{c}\text { Below } \\
\text { average } \\
\text { (28 \& below) }\end{array}$ & Total \\
\hline $\begin{array}{c}\text { Experimental } \\
\text { Group }\end{array}$ & 2 & 14 & 14 & 30 \\
\hline $\begin{array}{c}\text { Control } \\
\text { Group }\end{array}$ & 12 & 10 & 8 & 30 \\
\hline Total & 14 & 24 & 22 & \multicolumn{3}{|c|}{ Chi quare $\left(\mathrm{X}^{2}\right)=9.44$} \\
\hline \multicolumn{2}{|c|}{$\mathrm{df}=2$}
\end{tabular}

Findings: The null hypothesis has been rejected at 0.01 level of confidence which proves the effect of
Meditative-Prayer in reducing the level of Guilt feelings.

Null-hypothesis (2): There is no significant difference between the levels of Inferiority feelings of group subjected to meditative-prayer and the group not subjected to meditative-prayer.

\section{Percentage Table (2a):}

\begin{tabular}{|c|c|c|c|}
\hline Groups & $\begin{array}{c}\text { Above } \\
\text { average } \\
\text { (68 \& up) }\end{array}$ & $\begin{array}{c}\text { Average } \\
\mathbf{( 3 5 - 6 8 )}\end{array}$ & $\begin{array}{c}\text { Below } \\
\text { average } \\
(\mathbf{3 5} \text { \& below) }\end{array}$ \\
\hline Experimental Group & $10 \%$ & $50 \%$ & $40 \%$ \\
\hline Control Group & $30 \%$ & $63.33 \%$ & $6.67 \%$ \\
\hline
\end{tabular}

\section{Result Table (2b):}

\begin{tabular}{|c|c|c|c|c|}
\hline Groups & $\begin{array}{c}\text { Above } \\
\text { average } \\
\text { (68 \& up) }\end{array}$ & $\begin{array}{c}\text { Average } \\
(35-68)\end{array}$ & $\begin{array}{c}\text { Below } \\
\text { average } \\
\text { (35 \& below) }\end{array}$ & Total \\
\hline $\begin{array}{c}\text { Experimental } \\
\text { Group }\end{array}$ & 3 & 15 & 12 & 30 \\
\hline $\begin{array}{c}\text { Control } \\
\text { Group }\end{array}$ & 9 & 19 & 2 & 30 \\
\hline Total & 12 & 34 & 14 & \\
\hline \multicolumn{2}{|c|}{$\mathrm{df}=02$} & \multicolumn{3}{|c|}{ Chi-sqare $\left(\mathrm{X}^{2}\right)=10.06$} \\
\hline
\end{tabular}

Findings: This null hypothesis has been rejected at 0.01 level of confidence which proves the effect of Meditative-Prayer in reducing the level of Inferiority feelings.

Null-hypothesis (3): There is no significant difference between the levels of Insecurity feelings of group subjected to meditative-prayer and the group not subjected to meditative-prayer.

Percentage Table (3a):

\begin{tabular}{|c|c|c|c|}
\hline Groups & $\begin{array}{c}\text { Above } \\
\text { average } \\
\text { (60 \& up) }\end{array}$ & $\begin{array}{c}\text { Average } \\
\text { (27-60) }\end{array}$ & $\begin{array}{c}\text { Below } \\
\text { average } \\
\text { (27 \& below) }\end{array}$ \\
\hline $\begin{array}{c}\text { Experimental } \\
\text { Group }\end{array}$ & $6.67 \%$ & $53.33 \%$ & $40 \%$ \\
\hline Control Group & $36.67 \%$ & $36.67 \%$ & $33.33 \%$ \\
\hline
\end{tabular}


$\underline{\text { Result table (3b) }}$

\begin{tabular}{|c|c|c|c|c|}
\hline Groups & $\begin{array}{c}\text { Above } \\
\text { average } \\
\text { (60 \& up) }\end{array}$ & $\begin{array}{c}\text { Average } \\
(27-60)\end{array}$ & $\begin{array}{c}\text { Below } \\
\text { average } \\
\text { (27 \& below) }\end{array}$ & Total \\
\hline $\begin{array}{c}\text { Experimental } \\
\text { group }\end{array}$ & 2 & 16 & 12 & 30 \\
\hline Control group & 11 & 11 & 8 & 30 \\
\hline Total & 13 & 27 & 20 & \\
\hline \multicolumn{2}{|c|}{$\mathrm{df}=02$} & \multicolumn{3}{|c|}{ Chi-sqare $\left(\mathrm{X}^{2}\right)=07.96$} \\
\hline
\end{tabular}

Findings: This null hypothesis has been rejected at 0.05 level of confidence which proves the effect of Meditative-Prayer in reducing the level of Insecurity feelings.

In the present study, the effect of Meditative-Prayer was explored on feelings of Guilt, Inferiority and Insecurity. On completion of the study, and on the basis of the results obtained, it was observed that the null hypotheses were rejected at 0.01 level and 0.05 level of confidence. For Guilt feelings the value of $x^{2}$ is 9.44 which is greater than the value at 0.01 level, for Inferiority feelings the value of $x^{2}$ is 10.62 which is greater than the value at 0.01 level and for Insecurity feelings the value of $x^{2}$ is 7.96 which is greater than the value at 0.05 level but less than the value at 0.01 level of confidence.

\section{DISUCSSION}

The results show that there is significant effect of Meditative prayer on feelings of Guilt and Inferiority-Insecurity. One can alleviate mental and emotional problems with prayer. The best co-mingling of the mind, body and spirit takes place when one directs their heartfelt energies to getting well. Prayer has an effect on everything, from seed germination to wound healing. It can change the world. Prayer means to ask earnestly, beseech or implore. Prayer develops faith, devotion and self-confidence. Prayer is a cleansing process, washing our thoughts, feelings, motives, and will. Prayer cleanses the blockages of mind (Saraswati, 2002).
When prayer uplifts or calms, it inhibits cortisol, epinephrine, and norepinephrinehormones that flow out of the adrenal glands in response to stress. It in turn reduces oxygen use, increases blood flow, decreases blood pressure, relaxes muscles, improves brain functioning. Studies showed that after prayer, the fertility power increased by $10 \%$ in 200 sterile women. Many of the anti-depressants can be helpful in reducing the intensity of guilt. Prayer works as an anti-depressant (Sharma, 2004). Affirmative prayers release powers by which positive results are accomplished (Peal, 2003). In view of psychology, prayer is a type of autosuggestion which may help reduce stress and anxiety, promote a more positive outlook, and strengthen the will to live (Sharma, 1998).

Prayer can yield good results only when its philosophy and its true nature are properly understood. The more the mind gets concentrated, the stronger its power would be. True prayer in fact continuously fills up our pot of incompleteness. Initially to contact the divine, man resorts to prayer and at its highest, prayer becomes an aspiration from the soul for any worldly end (Gupta, 1996). "When a person himself or someone close to him prays to God, his or her prayer transforms the cells of the tissues of his or her body, and they become healthy. Prayer first affects the minute cells of the brain and then the cells of the body. In this way, even very difficult diseases are cured" (Jindal, 2005).

\section{Conclusion}

The human is mostly governed by emotions. When the mind becomes calm, when the outgoing senses have been restrained by sustained practices, when the mind cannot be easily affected by the evil influences, prayer becomes mental. Meditative prayer has the ability to release pent-up feelings and frustrations (Saraswati, 2002). It has been proved to be very helpful in present context where researchers applied it on persons who live 
with feelings of guilt, inferiority and insecurity, which are a real threat to the human psyche. The more one evolves, meditates, prays and pays attention to one's dreams and work to heal one's emotion, the more one can bring to consciousness these hidden beliefs (Mramor, 2006).

Meditative prayer washes off the impurities of the heart like the pure water of spiritual emotions, corrects the defects and shortcomings and prepares the mind for the reception of Self-knowledge. This Selfknowledge in turn enhances self-respect, confidence as well as responsibility in an individual. This results in efficacy of thoughts and a better functioning in day to day activities.

\section{MANJU DEORARI, Research Scholar,} Department of Yogic Science, Gurukul Kangri University; MRIGNAYANI AGRAWAL, Research Scholar; PRATIMA SHUKLA, Research Scholar, Department of Psychology, Dev Sanskriti Vishwavidyalaya, Haridwar, India.

\section{REFERENCES}

Atkinson, J., Berne, E. \& Woodworth, R. S. (1996). Dictionary of Psychology (p. 231). Delhi: Goyal Saab Publication.

Gupta, G. P. (1996). Management by Consciousness (p.144). New Delhi: Excel Books.

Hall, C.S., Lindzey, G. \& Campbell, J. B. (2002). Theories of Personality (p.131). Singapore: John Wiley \& Sons.

Harris, W.S., Gowda, M., Kolb, J. W., Strychacz, C. P., Vacek, J. L., Jones, P. G., Forker, A., O'Keefe, J. H. \& McCallister, B. D. (1999). A randomized, controlled trial of the effects of remote, intercessory prayer on outcomes in patients admitted to the coronary care unit. Archives of Internal Medicine, 159(19), 2273-8.
Hurlock, E. B. (2002). Personality Development (p.197). New Delhi: Tata McGraw Hill.

Jindal, R. (2005). Science of Natural Life (p.236). Modinagar: Arogya Seva.

Khokhar, C. P. (2003). Textbook of Stress Coping and Management (p.1). Meerut: Shalab Publication.

Mishra, O. P. \& Saini, R. (2007). The Bhramavarchas Guilt Feeling Test. Haridwar: Dev Sanskriti Vishwavidyalaya.

Mramor, N. (2006). Spiritual Fitness (p. 134). New Delhi: Fusion Books.

Page, J. D. (2003). Abnormal Psychology (p. 33). New Delhi: Tata McGraw Hill.

Pati, G. C. (1989). The Inferiority-Insecurity Scale. Agra: National Psychological Corporation.

Peal, N. V. (2000). The Power of Positive Thinking (p.59). Bhopal: Manjul Publication.

Saraswati, S. N. (1998). Prayer. Yoga Mimansa, 33(3), 27.

Saraswati, S. S. (2002). Essence of Bhakti Yoga (p. 7). Uttranchal: Divine Life Society.

Sharma, S. (1998). Upasana Samarpana Yoga (p.8.5). Mathura: Yug Nirmana Yojna.

Sharma, S. (2004). Prathana. Akhand Jyoti,03,7.

Sharma, S. (2005). The Meaning, Purpose and Benefits of Worship (p.28). Haridwar: Shri Vedmata Gayatri Trust.

Vasudevan, M. (2003). Emotional Stress (p.268). New Delhi: JayPee Brothers. 